\title{
J. J. ROUSSEAU'nun MÜZİĞİN KÖKENİ ve DOĞUŞU ile İLGİLİ DÜŞÜNCELERİ
}

\section{J. J. Rousseau's Thoughts about the Origin and Birth of Music}

Banu MUSTAN DÖNMEZ* Sultan BİLGET GÜÇLÜER***

\begin{abstract}
Bakın nasıl her şey bizi sürekli sözünü ettiğim tinsel etkilere götürüyor ve seslerin gücünü havanın etkisi ve tellerin titreşmesi olarak değerlendiren ne kadar çok müzisyen bu sanatın gücünün nerede yattı̆̆ını anlamaktan uzaklar. Onu sadece fiziksel etkilere yaklaştırdıkları ölçüde kökeninden uzaklaştırıyorlar ve astl enerjisinden yoksun birakiyorlar. Müzik, sözel vurguyu birakı sadece armonik yapılara bağlanarak kulağa daha gürültülü ve kalbe daha az yumuşak gelir hale bürünüyor. Müzik artık konuşmuyor zaten, yakında şark da söylemez olacak ve bütün o akorlarl ve armonisiyle üzerimizde hiçbir etki bırakmaz hale gelecek. (Rousseau, 2017, s. 77)
\end{abstract}

ÖZ

Bu çalışma, J. J. Rousseau'nun müziğin kökeni ve doğuşu ile ilgili düşünceleri üzerine oluşturulmuştur. Rousseau, sanatların, dilin ve müziğin kökenini Aristoteles gibi taklide (mimesis) ve estetik hazza (hoşlanma) dayandırmış; bu bağlamda müzik ve dilin kökenini insanın bilişsel yapısından kaynaklanan ortak bir kökenle ilişkilendirmiştir. Bir müzikolog ve besteci olan doğacı aydınlanma filozofu Rousseau, felsefi sistemini müzik üzerine olan düşüncelerine de yansıtmıştır. Rousseau, tıpkı eğitimde, siyasette, ekonomide olduğu gibi bilimde ve sanatta da doğanın temel alınması gerektiğini savunmuştur. Bu nedenle sanatın öğrenilmesi ve icrası ekseninde aşırı karmaşı ve duygudan yoksunlaşmış görünen yeni haline (armoni sanatı, modern notasyon sistemi, müzikal tonların majör-minöre indirgenmesi, sözlerin müzikten ayrılması ve müziğin çalgısal müziğe indirgenmesi gibi) eleștirel yaklaşmıştır. Rousseau'nun temel çalıșma alanı felsefe olduğundan, O'nun müzik teorisi ve bestecilik üzerine tam tekmil bir performans sergilemesi beklenemezdi. Ancak burada filozofun müzikoloji açısından en önemli yönü, müzik üzerine ortaya attığı düşüncelerin kendi felsefi sistemiyle olan bağlantısı ve geleceğe yön vermesidir. Doğayla uyumlu ve arı felsefesinin bilim ve sanat anlayışına da yansıması; müziği hakikati kavratan bir gereç olarak algılaması ve bu yönüyle Antikiteye özenmesi; dolayısıyla müziğin gösterişli yönünden çok özünü kavramaya ve sonraki kuşaklara aktarmaya yönelik düşünsel yaklaşımına uygun, basit nota yazım yöntemleri tasarlaması; söz ve melodiye de, doğayı taklite daha uygun olması yönüyle armoniden daha fazla değer vermesi, bu filozofun düşünceleri, söylemleri ve uygulamaları arasındaki doğrusallığı göstermesi açısından önemlidir.

Anahtar Kelime: J. J. Rousseau, Aydınlanma, Müziğin Kökeni, Müziğin Doğuşu, Taklit Kuramı

\section{ABSTRACT}

This study focused on Jean-Jacques Rousseau's thoughts on the origin and birth of music. Like Aristotle, Rousseau traced the origins of arts, language, and music to imitation (mimesis) and aesthetic pleasure (delectation). He associated the origin of music and language with a shared origin arising from human cognition. A musicologist, composer, and naturalist enlightenment philosopher, Rousseau's philosophical system was translated into his thoughts on music as well. He advocated that, just like education, politics, and economics, science and art should be based on nature, too. For this reason, he critically approached the new state of art, which seems overly complex and devoid of emotion in the axis of learning and performance (e.g., harmony, modern notation system, musical tones reduced to major-minor tonality, lyrics separated from music, and music reduced to instrumental music). Rousseau was, above all, a philosopher. Therefore, it would be unreasonable to expect him to have a full performance on music theory and composition. However, his essential role in musicology was due to the relation between his thoughts on music and his philosophy, steering the future. The reflection of his pure philosophy, which was compatible with nature, on his understanding of science and art is critical because it shows the linearity between his thoughts, discourses and practices. He considered music a means of grasping the truth and in that sense, he admired Antiquity. He designed simple notation methods in line with his idea of capturing the essence of music and passing it down to future generations rather than fixating on its flashy features. Rousseau appreciated lyrics and melody more than harmony because, to him, they were more suitable to imitate nature and non-temperamental systems.

Key Words: J. J. Rousseau, Enlightenment, Origins of Music, Genesis of Music, Mimesis

Araştırma Makalesi/Research Article Geliş Tarihi/Received Date: 24.04.2021 Kabul Tarihi/Accepted Date: 20.05.2021

* Sorumlu Yazar/Corresponding Author: Prof. Dr., Ankara Müzik ve Güzel Sanatlar Üniversitesi, bmustandonmez@mgu.edu.tr, ORCID ID: 0000-0002-0503-3122

** Öğr. Gör, Adıyaman Üniversitesi Devlet Konservatuarı, sbilgetgucluer@adiyaman.edu.tr, ORCID ID: 0000-0002-50709355 


\section{Extended Abstract}

When music becomes noisier to the ear and less sweet to the heart, it is an indication that music has already ceased to speak; soon it will no longer sing, and then, with all its chords and all its harmony, it will no longer have any effect on us" (J. J. Rousseau).

Jean-Jacques Rousseau was born in 1712 to a Protestant family of French origin living in Geneva, Switzerland, and died in 1778 in Ermenonville in France. Rousseau is a versatile enlightenment philosopher with scientific endeavors in many fields from philosophy to politics and sociology to music theory and composition. Unlike many thinkers, Rousseau approaches sciences and arts from an ethical perspective. As a social enlightener, Rousseau argues, especially in his book titled The Discourse on the Arts and Sciences, that sciences and arts have an unethical foundation. According to him, luxury and morality are mutually exclusive, and science and art that cannot rid themselves of luxury cause social degradation and destroy genuine human relationships, resulting in humans being alienated from their own nature and losing their true selves. Rousseau claims that the society in which he lives is engaged in collective hypocrisy. As in other subjects, he appreciates "the essence" in science and art.

From a broader perspective, composition, music theory, and musicology are essential parts of Rousseau's intellectual life. He is unique in that sense. He is both a composer, a theoretician, an encyclopedist, and a musicologist. He composes operas (Oransay 1977, p. 120), authors a dictionary of music (Rousseau, 1975), presents a new system of numbered musical notation to the Academy of Dijon in 1742, and writes letters and essays on the origin of music, the relationship between music and languages, French music, and a critique of music of his time and J. P. Rameau's theory.

The "origin of music" is a particular concept containing many questions, problems, and answers concerning the etymology and definition of the word "music," musical elements, the birth of music, its ontology, contexts, functions, relation to instruments, and its presence in Western and non-Western cultures, its transformation in parallel to animal and human evolution, its physical and acoustic foundations, and its relation to culture (Mustan Dönmez, 2019, p. 129). Rousseau's theories on the origin of music are based on a linguistic and imitative perspective. We can clearly see this trend in his work titled Essai sur l'origine des langues Où Il Est Parlé de la Mélodie et de l'imitation Musicale (1781).

Some of Rousseau's thoughts on music are based on the Aristotelian theory of imitation (mimesis). Rousseau regards music as a harmonious, poised, and concordant art of mimesis. He describes music as a complement of nature and constructs his thoughts on this axis. Based on the theory of mimesis, Rousseau considers melody superior to harmony. He advocates that melody describes not only the sounds of nature (thunder, rush of waters, wind, and storm) but also moods (anger, cry, pain, and joy) much better than harmony. Rousseau states that music cannot come into being without adding an aesthetic gesture to musical and linguistic imitation. In this way, he associates art with the impulses of "mimesis" and "pleasure," as stated by Aristotle in art theory (Aristoteles, 2001, p. 16).

Rousseau primarily divides the ways of expressing thoughts and feelings into "visual" and "auditory" and calls visual communication "movement" and auditory communication "sound." He categorizes movement as touch and 
gestures and sounds as language and music. To him, the first gestures create visual communication, while the first sounds out of strong emotions create auditory communication (Rousseau, 2017, p. 1-9). From this perspective, just like his enlightened successor Herder (1744-1803), Rousseau thinks that music originates from the triangle of dance-melody-language, in the sense of audio-visual integrity of communication (Herder and Bohlman, 2017, pp. 249-260).

Rousseau thinks of languages and music as of the exact origin because, to him, the first language is full of emotions and metaphors, prosody is present in both languages and music, sentences bearing words turn into poetic and musical expressions of rhythmic divisions (examples of the first folk literature and music), and transformation evolves and results in structures of rhythm, melody, and harmony.

Rousseau claims that the music of his time strays from its essence, just like civilization, science and art. To him, the perfection of language imposes rules on melody and restricts it, and the melody that has taken over by rules gradually loses its ancient energy. He asserts that the calculation of intervals has replaced the subtlety of inflections. According to him, the art of stirring has been lost as the art of convincing has been cultivated (Rousseau, 2017, p. 81-82).

Rousseau criticizes the temperamental system in music because it causes an order of mechanical intervals that is not present in nature, and the harmonic formation that draws its power from the temperamental system restricts the melodic expression and mobility. He also criticizes instrumental music for destroying the verbal depth and expression of music. To him, lyrics that make up the meaningful structure of music are ignored, and language, with perfection, is stripped off melody, which becomes autonomous. Therefore, the departure of musical elements from each other in this form destroys the holistic understanding of Greek tragedies and corrupts music. 


\section{Yy. J.J. Rousseau Dönemi Avrupası’nda Düşünce İklimi}

Rousseau, 28 Haziran 1712 tarihinde, İsviçre'nin Cenevre kentinde Fransız kökenli Protestan bir ailede doğmuş, 2 Temmuz 1778 günü Fransa'nın Ermenonville Kenti'nde vefat etmiştir (1712-1778). Rousseau, bir aydınlanma dönemi filozofudur. "Aydınlanma” terimi, Avrupa Uygarlığı tarihinde 17. yüzyılın son çeyreğinde başlayıp 18. yüzyılın sonlarına kadar uzanan bir döneme işaret eder (Cevizci, 2008, s. 11). Kant, aydınlanmayı: “İnsanın kendi suçuyla düşmüş olduğu bu ergin olmayış durumundan kurtulması...” (Cevizci, 2017, s. 13) olarak tanımlar. Aydınlanma, dinsel dogmaların baskıcı etkisinden sıyrılıp aklı ve bireyi önceliğe alan, özellikle 18. yüzyıldan itibaren Batı toplumlarının düşünme biçiminde ve sosyal normlarında büyük değişmelere neden olan hümanist bir felsefedir. Aydınlanma Çă̆g'nı oluşturan düşünsel temellerin evveliyatı ise Rönesans-Reform hareketleri ve coğrafi keşiflerle başlayıp 1789 Fransız İhtilali ile doruğa ulaşan uzun bir süreci içine alır (İşler, 1999, s. 49). Aydınlanma felsefesi, doğal hakların toplum yaşantısı içinde korunması için önlemler alır, insana güven duyar ve insanı, aklını kullanarak gerçek olana ulaşabilecek bir varlık olarak nitelendirir. Bu eksende de Ortaçağ’ın düşünce yapısından uzaklaşır (Topses, 2010, s. 1). Rönesans düşüncesi ise 17. yüzyılda Descartes, Spinoza, Leibniz gibi filozofların büyük felsefe sistemleriyle olgunlaştıktan sonra, daha çok bir kültür felsefesi olan 18. yüzyıl felsefesine taşıdıkları olanakları geniş ölçüde sağlayacaktır (Engineri, 2008, s. 1-2).

Aydınlanmacı düşün yapısı, Ortaçağ baskıcıllı̆ından bireyi kurtararak akla, insana, bireysel özgürlüğe odaklanmış ve bu düşün yapısı ile özgür düşünme alanı yaratılarak herkesin eşit olduğu bir dünya tasavvur edilmiştir. Dolayısıyla bu dönemde doğaya ve doğal olana yönelinerek emeğe ve halka verilen kıymet artmış; saray kültürünün elitist hiyerarşisine dayanan beğeni anlayışı bir miktar ters yüz olmuştur. İşte bu süreçte Rousseau, aydınlanma dönemi filozofları arasında yer alsa da özellikle Bilimler ve Sanatlar Üzerine Söylev (1750), Insanlar Arasındaki Eşitsizliğin Kaynağı (1755), Toplum Sözleşmesi (1762), Emile (1762) gibi eserlerinde Aydınlanma Döneminin eşitliksiz kalkınma felsefesine belirli bir muhaliflik de oluşturmuştur.

\section{J. J. Rousseau'nun Felsefesi}

Rousseau; felsefe, politika, sosyoloji, hukuk, sanat, müzik teorisi ve bestecilik gibi birçok alanda çalışmaları olan çok yönlü bir fillozoftur. Çok yönlülüğü, yazdığı kitap ve makalelerindeki geniş konu yelpazesinden de anlaşılmaktadır. Ancak eserlerinden hareketle şu söylenebilir ki; Rousseau'nun çalışmalarının ana omurgasını sosyolojik, politik ve eğitsel konular oluşturmaktadır:

Aydınlanma geleneği içerisinde nispeten daha ayrıntılı ve eleştirel bir konum işgal eden Rousseau, insan doğasının eğitim ve sosyal reformlar yoluyla istenildiği gibi şekillendirip sınırsızca geliştirilebileceğine, hatta yetkinleştirilebileceğine inanan tam bir aydınlanma düşünürüdür. Rousseau, diğer aydınlanma düşünürlerinden farklı olarak uygarlaşmış, aydınlanmış var oluşun olumsuzluk ve kötülüklerini teslim eden, rasyonalist olmayan duygucu bir filozoftur. (Cevizci, 2007, s. 264)

Dolayısıyla "Rousseau aydınlanması", aydınlanmanın doğacılık ve duygusallıkla birleştiği kendine özgü bir yol çizer; hatta Aydınlanma Dönemi’nin aklı, bireyi ve bilimi "kült” haline getirdiği düşünülecek olursa Rousseau, bunların gerekliliğini ve etik açıdan uygunluğunu tekrar sorgulayarak, aslında Aydınlanma felsefesinin özüyle de kısmen çelişmiş olmaktadır. 
Rousseau doğacıllğı, ilkelizm değildir; çünkü Rousseau, uygarllğa değil uygarlı̆̆ın etik ve adaletli olmayan yönlerine karşıdır; bilime ve sanata değil bilim ve sanatın sınıflar arası uçurumu ve adaletsizliği körükleyen yönlerine karşıdır. Dolayısıyla Rousseau, sanatı ve uygarlığı ortadan kaldırmak değil ıslah etmek istediği ve bunu yaparken doğal hayatı nirengi noktası olarak düşündüğü için "ilkelist" değil "doğacı" olarak addedilmelidir (Lovejoy, 1923, s. 165-186).

Alfred Weber, Rousseau'cu aydınlanma için şu ifadeyi kullanır: "Kudretli bir biçimde ahlaki ve sosyal fikirlere hareket vermiştir. Dış otoriteye ve akla duyguyu, medeniyete ve onun sefaletlerine tabiatı, tahammül edemediği topluma bireyi ve onun elinden alınamayan haklarını koyarak, herkesten fazla geleceğin siyasi ve sosyal sarsıntılarına başlangıç oluyor" (Weber, 1991, s. 291). Bakır'a göre onun düşünceleri, önemini etkisinin büyüklüğünden alır; Fransız İhtilali’nin ve Aydınlanmanın tohumları olarak da görülebilir (Bakır, 2007, s. 105).

Rousseau, eski ve yeni sanat sistemi arasında kalmış bir düşünürdür. Hatta çağdaşları bile kendisini, çelişki değilse bile bir paradoks içinde olmakla, bir yandan güzel sanatları ahlaki yozlaşmanın bir tezahürü olarak reddederken öte yandan da opera, oyun ve roman yazmaya devam etmekle suçluyordu. Shiner, bazı bilginlerin Rousseau'nun bu iki yönünü uzlaştırmaya ve Rousseau'yu modern estetiğe daha uygun hale getirmeye çalıştıklarını ifade etmektedir. Shiner'ın kişisel görüşü ise Rousseau'nun insanlara daha çok öğreten tarafının ikircikliliği olduğu yönündedir (Shiner, 2017, s. 229).

Rousseau'ya göre bilim, sanat ve edebiyat, iktidarın tekelinde öz niteliğini kaybetmiş; insanların ruhlarını ve ahlakını bozduğu gibi geleneklerinin de çöküşüne yol açmıştır. Rousseau, "özgür, dürüst ve mutlu” yaşamanın, bahsi geçen arkaik ${ }^{1}$ süreç içerisinde var olabildiğine inanmaktadır:

İnsanlar, kaba saba kulübeleriyle yetindikleri, keskin taşlar kullanarak kayık yaptıkları, basit müzik aletleri yaptıkları, kısaca tek bir insanın yapabileceği işleri üstlendikleri ve birçok kişinin ortaklaşa çalışmasını gerektirmeyen zanaatlarda bulundukları sürece; yapıları el verdiği ölçüde, karşılıklı ve bağımsız ilişkiden keyif almayı sürdürdükçe "özgür, dürüst ve mutlu” hayatlar yaşadılar. Fakat insan, bir diğerinin yardımına koşmaya başladıktan; her bireye, iki kişilik erzak sağlamak avantajı geldikten sonra; eşitlik ortadan kalktı, "mülk kavramı" ortaya çıktı... (Rousseau, 2003, s. 73)

Rousseau için bu süreç, zanaatın sanata dönüşmediği, sanatın karmaşadan uzak ve basit bir formda günlük yaşamın ayrılmaz parçası olduğu zamandı; ta ki mülk kavramı ortaya çıkana kadar.

Birçok düşün insanından farklı olarak Rousseau'nun bilimlere ve sanatlara yaklaşımı, etik bir perspektif çevresinde döner. Rousseau, toplumcu bir aydınlanmacı olması nedeni ile özellikle Bilimler ve Sanatlar Üzerine Söylev adlı eserinde, bilimlerin ve sanatların da tıpkı siyaset gibi etik olmayan bir temel üzerine oturduğunu savunur:

Bilimlerin ve sanatların gelişmesi, ahlakın düzelmesine yardım etmiş midir?" sorusuna yanıt veren en iyi denemeyi yazdığı için “Dijon Akademisi”nden ödül almıştır. Rousseau, bu soruya yalnızca ünlü söylevi ile

\footnotetext{
${ }^{1}$ Buradaki anlamı itibarıyla arkaik, "eskimiş", "kullanılamaz hale gelmişs" veya "tedavülden kalkmış" anlamında bir sıfat olup, çalışma içinde insanlığın eski, hatta tarih öncesi dönemlerine göderme yapar.
} 
değil, bütün hayatı ve eserleriyle "hayır" cevabını vermiştir. Rousseau, ölünceye kadar bu söylevdeki

fikirlerine bağlı kalmış ve bütün eserleri, sanki aynı fikirlerin genişletilmesi ve ispatlanması için yazılmıştır.

(Eyüboğlu önsözü Rousseau, 2018, s. V)

Rousseau, insanın ürettiği bilgiyi sert bir şekilde eleştirmiş ve bu bilginin güzel bir kaynağı olmadığını şöyle ifade etmiştir:

Astronomi, boş inançlardan doğmuştur; güzel söz söylemek hırstan, kinden, dalkavukluktan, yalandan; geometri cimrilikten; fizik, boş bir meraktan ve hepsi birden, hatta ahlak bile, insanın kendisini beğenmesinden doğmuştur... Lüks olmasaydı, lüksün beslediği sanatları ne yapardık? Haksızlıklar olmasaydı, hukuk bilimi ne işimize yarardı? Zalim hükümdarlar, savaşlar, isyanlar olmasaydı tarih ne olurdu? Kısacası herkes yalnız insanlık görevlerini ve doğal ihtiyaçlarını düşünseydi, yalnız vatanını, mutsuz insanları ve sevdiklerini korumaya zaman bulsaydı, hayatını bu boş düşüncelere dalmakla geçirmek kimin aklına gelirdi? (Rousseau, 2018, s. 19-20)

Rousseau, lüks ve ahlakın birbirlerinden kopuk olduğunu söylerken, lüksten ayrılmayan bilim ve sanatın toplumu bozduğunu, gerçek insan ilişkilerini yok ettiğini ve bu şekilde de insanın kendi doğasından uzaklaşarak gerçek benliğini kaybettiğini vurgulamaktadır. Rousseau'ya göre lüks, insanları maddi zenginliğe yöneltirken ahlaki değerlerin çökmesine sebep olmuştur.

Öz olarak Rousseau, içinde yaşadığı toplumun ahlaki bakımdan kolektif bir ikiyüzlülük içerisinde olduğunu savunmuş, ele aldığı diğer konular gibi bilim ve sanatta da öz olanı kıymetli bulmuştur. Fakat tüm bu uğraşlarına karşın Rousseau, yaşadığ dönemde birçok eleştiriye maruz kalmıştır. Rousseau'nun etik, estetik, eğitsel ve sosyal yozlaşmaya neden olduğunu düşündüğü 'lüks'e yüklediği bu negatif anlamın, kapitalist ekonomik sistemi acımasızca eleştiren toplumcu felsefenin çağından önce açmış erkenci bir ilham kaynağı olduğunu burada ayrıca vurgulamak gerekir.

Bir bütün olarak felsefesinde olduğu gibi, Rousseau, modern felsefenin "indirgemeci materyalizm" olarak gördüğü şeye karşı çıkar ve doğal, kültürel veya sosyal güçlerin karşıllklı etkileşimine katılan bir öğreti sunar. Rousseau, indirgemeci müzik ve siyaset teorilerine bir alternatif olarak, doğal, ahlaki veya kültürel güçlerin karmaşık etkileşimine katılan ve iyi zevk ve erdemi geri getirmeye adanmış bir felsefe önermiştir (Scott, 1997, s. 813-827). Rousseau'nun müzik üzerine olan düşünceleri de, genel felsefesinden bağımsız değildir. İlerde müziğin "doğuşu”, "gelişimi” ve “yozlaşması” ile ilgili düşüncelerini ele alınırken, bu durum vurgulanacaktır. 


\section{J. J. Rousseau'nun Müziğin Kökeni ve Doğuşu ile İlgili Düşünceleri}

\section{Rousseau'nun Besteciliği, Müzik Teorisyenliği ve Müzikologluğu Üzerine}

Rousseau; felsefi, sosyolojik ve edebi alanların yanında 1730-31 yılları arasında müzikle de ilgilenmeye başlamıştır. Filozof, müziğe ilk adımını Warens ${ }^{2}$ 'in tavsiyesiyle kilise korosuna girerek atmıştır; paraya ihtiyacı olduğu için, müziği çok iyi öğrenememiş olmasına rağmen Lozan'da yer alan konserlerde seslendirilmesi için eserler yazmaya başlamıştır. Daha sonra konser verdiği kenti bırakıp Neuchatel'e gitmiştir. Rousseau, burada müzik dersi alacak öğrenciler bularak hem ders vermiş hem de bu sayede müziği kendi kendine öğrenmeye başlamıştır (Alsan, 1962, s. 11). Buradan da anlaşılacağı üzere çoğunlukla yaşamını nota kopya ederek kazanmış olan Rousseau, müzik konusunda tam bir eğitim alamamış olmasına rağmen kendi çabalarıyla müzik alanında var olma ve üretme sürecine dâhil olmuştur (Akan, 2017, s. 25). Rousseau'nun toplum, siyaset, eğitim, hukuk gibi beşeri alanlar üzerine çalışmaları olan önemli bir filozof olmasının yanı sıra bestecilik, teorisyenlik ve müzisyenlik alanında çağının diğer müzik insanları kadar ön plana çıkamadıysa da yadsınamaz bir ün kazandığı aşikârdır. Tylor, bu durumu şu şekilde ifade eder: "Söylediğim gibi Rousseau, yalnızca ünlü bir siyaset felsefecisi değildir. 18. yüzyılın ortalarında, müzik yazarı olarak dikkate değer bir ün kazanmıştır” (Tylor, 1949, s. 232).

Fakat Shiner, Rousseau'nun bu ünü neden istediği yönünde farklı bir perspektif sunar. Shiner, 18. yüzyılda bir yerlere gelmeye çalışan pek çok genç gibi Rousseau'nun da müzik ve edebiyatı zarif bir topluma giriş olarak kullanmayı umduğunu belirtmektedir (2017, s. 229). Rousseau, İtiraflar kitabında müziği ve edebiyatı, yaşamı boyunca geçirdiği sıkıntılı ve zorlu günlerin çıkış kapısı olarak gördüğünü ifade etmektedir: "Bugün içinse aklımı fikrimi müzik sistemime verdim ve onun sayesinde müzik sanatında bir devrim yaratmak, bu yoldan da şöhrete ulaşmak gayesine sarıldım; çünkü Paris’te güzel sanatlar alanında şöhret yapmak demek, daima servet sahibi olmak demektir" (Rousseau, 1991, s. 20).

Belki de Rousseau için, şöhretin kapılarını açacağını düşündüğü "notasyon sistemi”, büyük bir adımdı. Fakat Rousseau'nun 22 Ağustos 1742'de Dijon Bilimler Akademisi'ne sunduğu Yeni Müzik İşaretleri Hakkinda Projesi de İtiraflar kitabında yazdıklarından anlaşılacağı üzerine hayal kırıklığı ile sonuçlanmıştır: "Eserimi incelemek üzere seçilen komisyon üyeleri M. M. de Mairan, Hellot ve Fouchy idi. Üçü de şüphesiz değerli kişilerdi, ama hiçbiri müzikten anlamıyordu, hiç değilse teklifim hakkında hüküm verebilecek derecede müzik bilmiyorlardı" (Rousseau, 1991, s. 17) diyerek inceleme komisyonuna serzenişte bulunmuştur.

Ayrıca yapılan itirazların çoğunun zayıf ve hatalı olduğunu vurgulamakta ve "Pere Souhaitti” adında bir keşişin nota sistemi ile kendi nota sisteminin mukayese edilmesine de oldukça içerlediği görülmektedir. Düşüncelerini şu şekilde ifade eder:

Pere Souhaitti’nin hiç adını duymadığım bir yana, onun oktavları bile hesaba katmadan kilise müziğinin yedi sesini kaydetmekten ibaret olan notalama usulü, benim rakamların yardımıyla her türlü müziği, anahtarları, durakları, oktavları, usulü, temposu ve nota kıymetleriyle kolayca kaydetmeye yarayan sade ve rahat sistemim ile mukayese dahi edilemezdi; böylesine bir notalama usulü Pere Souhaitti'nin aklından bile geçmemişti...

2 Warens, Françoise-Louise de: Rousseau'nun "İtiraflar" eserinde de kalemine aldı ̆̆ı, 1728 de tanıştı̆̆ Rousseau'nun hamiliğini yapan ve aynı zamanda Rousseau ile aralarında ilişki bulunan kadın (Rousseau, 1991, s. 223). 
Benimkinin en önemli üstünlügü̈, transpozisyonları ve anahtarları ortadan kaldırmasında idi; böylece aynı parça, baş tarafa konulan bir tek harfin değişmesiyle, istenilen tonda hem yazılmış hem de o tona transpoze edilmiş oluyordu. (Rousseau, 1991, s. 18)

Rousseau, komisyonunda yer alanların eleştirilerini yersiz bulurken, yaptığı çalışmayı savunamamaktan da yakınmıştır: "Başarı apaçıktı, fakat duyulmadı. Benim yerime başkası olsaydı gazeteler dolusu yazı yazardı; fakat işe yarar şeyler keşfetmekte az çok kabiliyeti olan ben, bunları değerlendirmekte hiç bir zaman kabiliyet gösteremedim" (Rousseau, 1991, s. 21-22). Bu söylemlerinden de anlaşılacağı üzere çok fazla kafa yorduğu ve faydalı olacağına inandığı nota sisteminin dikkate alınmaması, eleştirilmesi ve başka bir nota sistemi ile benzer gösterilmesi Rousseau’yu olumsuz yönde etkilemiş ve hayal kırıklığına uğratmıştır.

Geniş bir perspektiften bakılarak değerlendirme yapıldığında bestecilik, müzik teorisyenliği ve müzikologluk, Rousseau'nun entelektüel yaşamının önemli bir parçasıdır. Bu yönüyle Rousseau, bir özgünlük arz eder. Rousseau'nun besteciliği opera besteciliği biçimindeyken (Oransay 1977, s. 120); teorisyenliği, ansiklopedist olarak bir Müzik Sözlüğü yazmış olmasından (Rousseau, 1975) ve 1742'de Dijon Bilimler Akademisi'ne sunduğu Yeni Müzik Işsaretleri Hakkında Proje adlı yeni nota yazımı önerisi gibi faaliyetlerinden ileri gelir. Müzikologluğu ise müziğin kökeni, dillerle ilişkisi, dönemindeki müziğin ve J. P. Rameau teorisinin eleştirisi ve Fransız müziği üzerine yazmış olduğu mektup ve diğer deneme yazılarından ileri gelir. Tylor’un ifadesindeki gibi: “Rousseau’nun müziksel perspektifindeki zenginlik, onun besteciliği ve ya icracılığının gücünden değil, fakat müziğin mekanizması hakkındaki dikkate değer bilgilerinden kaynaklanır” (Tylor, 1949, s. 232).

Rousseau'nun müziğe olan yaklaşımı, ileride detaylandırılacağı üzere onun siyaset, sosyoloji ve eğitim anlayışını temellendirdiği “aydınlanmacı-doğacı” düşüncelerinden bağımsız değildir; bu alanda da doğal ve kolay olana ulaşma, duygularını aracısız, direkt ifade edebilme isteği ön plana çıkmıştır. Bu düşünce etrafında çalışmalarını sürdürmüş ve Batı müziği tarihi içinde de belirli bir etkiye sahip olmuştur.

\section{“Müziğin Kökeni” Kavramı Üzerine}

Müziğin kökeni kavramı, müzik sözcüğünün etimolojisi ve tanımı, müziksel öğelerin neler olduğu, müziğin doğuşu, ontolojisi, bağlamları, işlevleri, çalgılarla ilişkisi, Batı ve Batı-dışı (non-Western) kültürler içerisindeki varlığı, hayvan ve insan evrimiyle koşut evrimi, fiziksel ve akustik temelleri, kültürle ilişkisi gibi birçok soru, sorun ve yanıtı içeren özel bir kavramdır. Bu alanda Rousseau (1781), Stumpf (1911), Wallin-Merker-Brown (2001), Mithen (2006), Morley (2013), Thomas (1995) ve Mustan Dönmez (2014) gibi birçok yazara ait farklı çalışmalar bulunmaktadır (Mustan Dönmez, 2019, s. 129-131). Müziğin kökenine ilişkin her konu, müziğin anlaşılması için gerekli olan felsefi soruşturmanın oluşumunu sağlar. Ancak müziğin kökeni dendiğinde asıl anlam, müziğin oluşumu, yani doğuşudur. “...Müziğin doğuşuna ilişkin teoriler, nihayetinde insana bağlanmak durumundadır. Müzik, insanın bilişsel gelişkinliği ile ilgili bir ses kodlama sistemidir” (Mustan Dönmez, 2015, s. 45).

$\mathrm{Bu}$ çalışmanın ilerleyen bölümlerinde, Rousseau'nun Aristotelesçi mimesis (yansıtma/ taklit) kuramına dayanan müzik anlayışını, alandaki temel eserlerinden biri olan Melodi ve Müziksel Taklit ile İlişki Iç̧inde Dillerin Kökeni Üstüne Deneme adlı çalışmasında ne şekilde ele aldığı üzerinde duracağız. Böylece, Rousseau'nun ağırlıklı 
olarak müziğin doğuşu ve gelişimine odaklandığı temel teorilerini kritize edeceğiz. Bu teoriler, geniş bir kavram havuzuna sahip olan "müziğin kökeni" meselesinin daha çok "dilsel" ve "evrimsel" perspektifler üzerine oturmaktadır.

\section{Taklit (Mimesis) Kavramı ve Rousseau'da Müziksel Taklidin Yorumu Üzerine}

Bu noktadan itibaren, Rousseau'nun müziğin oluşumu ile ilgili düşüncelerini tam olarak anlayabilmek için, öncelikle müziği ve diğer sanatları neye dayandırdığını detaylandırmak gerekir. Taklit (mimesis), Antik Yunan'da temelleri Aristoteles tarafından atılmış bir "sanat kuramı"dır. Aristoteles, sanata bütüncül bir biçimde yaklaşmakta ve dönemi içerisindeki şiir sanatını, tüm sanatların (koro, müzik, edebiyat, drama, dekor, kostüm) toplamı olarak görmektedir. Filozof, sanattaki taklit (mimesis) kuramını o kadar ön plana çıkarmıştır ki Poetika (şiir sanatı) adlı eserinin hemen hemen tamamını taklit biçim ve yöntemlerine göre kategorize etmiştir. Poetika adlı eserinde filozof, şiiri oluşturan sanatları "taklit araçları", "taklit nesneleri” ve "taklit tarzı" olarak birbirinden ayırmıştır. Sanatlar içerisindeki taklit araçlarını "görsel gereçlerle" taklit edenler (renk ve figürler) ve "işitsel gereçlerle" taklit edenler (ritim, söz, armoni) olarak kategorize etmiştir. Sanatlar içerisindeki taklit nesnelerini ise genel hatlarıla eylemde bulunanlardan yola çıarak "ortalamadan iyi karakterlerin taklidi" (tragedya) ve "ortalamadan kötü karakterlerin taklidi" (komedya) olarak kategorize etmiş̧ir. Sanatlar içerisindeki taklit tarzını ise "hikâye ile anlatma" (mit ve destan) ve "rol ile anlatma" (drama) olarak kategorize etmiştir (Aristoteles, 2001, s. 11-14).

Rousseau'nun müzik üzerine olan düşüncelerinin bir kısmını da Aristotelesçi taklit (mimesis) kuramı oluşturur. Rousseau müziği; uyumlu, dengeli ve ahenkli bir taklit sanatı olarak görmüş, doğanın tamamlayıcısı olarak nitelendirmiş ve bu eksende düşüncelerini ifade etmiştir. Ancak öncelikle Rousseau'nun, müziğin ne şekilde taklit ettiği ile ilgili düşüncesini burada ele almak gerekir. Rousseau, müziğin ruh üzerindeki etkisinin kesinlikle bildik seslerin ürünü olmadığını savunur ve bu etkiyi melodiye bağlar. Zaten Rousseau'nun taklit (mimesis) teorisinden yola çıkmış olması, onun müziksel unsurlar içerisindeki melodiyi armoniden üstün tutmuş olmasının ana nedenidir. Filozof, yalnızca "gök gürültüsü", "suların çı̆̆ıltısı", "rüzgâr ve firtınalar" gibi doğa seslerinin değil, aynı zamanda "öfke", "feryat", "acı" ve "neşe" gibi duygu durumlarının da melodi tarafindan armoniye göre çok daha iyi betimlediğini savunmaktadır.

Filozof, müziğin sesleri kulağa hoș gelecek biçimde bir araya getirme işlevini tek başına eksik bulmaktadır: "Müzik bundan ibaret olsaydı doğa bilimlerinden sayılırdı, güzel sanatlardan değil. Onu bu düzeye çıkaran sadece taklit etmedir" (Rousseau, 2017, s. 63). Filozof, tıpkı resim sanatının ana unsuru olarak algıladığ 1 "desen”i resimde taklit sanatının ana gereci olarak gördüğü gibi müzik sanatının ana unsuru olarak algıladı̆̆g "melodi”yi de taklit sanatının ana gereci olarak görmüştür.

Rousseau'da insan sesi vurgulamaları ayrıcalıklıdır ve armoninin karşısında konumlandırılmaktadır, zira onlar tutkuları ifade eder ve doğayı mükemmel biçimde taklit eder. Resimde doğanın formlarını konturların taklit etmesi gibi, sesin vurgulamaları da doğayı taklit eder (Ertuğrul, 2020, s. 58). "Gırtlaktan çıkan seslerdeki ton değişikliklerini taklit eden melodi yakınmaları, acı ya da sevinç dolu haykırışları, tehditleri, iniltileri dile getirir. Güçlü duygulanımların bütün sesli işaretleri, onun yetki alanındadır” (Rousseau, 2017, s. 66). Rousseau, müziğin taklit nedeni ile insan sesinden ve dolayısıyla dilden doğuşunu şu şekilde ifade eder:

Öfke, dil ya da damağın eklemlediği korkutucu çığlıklar çıkarır; oysa şefkatin sesi daha yumuşaktır, onu değişime uğratan gurtlaktır, böylece bu ses, belirli bir tek ses haline gelir... Böylece ahenk ve tek tek sesler de 
hecelerle doğar, güçlü duygulanım bütün organları konuşturur ve insanın sesini onların bütün görkemiyle donatır; böylece şiirlerin, şarkıların ve sözün ortak bir kökeni olur. ...Illk söylemler, ilk şarkılar olmuştur: Ritmin yinelenen ve ölçülü dönüşleri, vurgulardaki melodi ve ton değişimleri, dille birlikte şiiri ve müziği doğurmuştur. (Rousseau, 2017, s. 57)

Rousseau'ya göre taklit etmenin de bir niteliği olmalıdır. Taklit yapılırken doğanın sesinin tanımlanması gerekmektedir. "Gürültüyü gürültüyle anlatmak isteyen müzisyen yanılır; sanatının ne güçlü yanını ne de zayıf yanını tanıyordur... Çünkü basitçe taklit etmesi yetmez, etkilemesi, hoşa gitmesi gerekir; bunlar olmadan sıkıcı taklit hiçbir şey değildir. Kimsenin ilgisini çekmeyeceğinden hiçbir etki uyandırmayacaktır" (Rousseau, 2017, s. 68). Eş deyişle Rousseau, müziksel ve dilsel taklide estetik bir espri eklenmeksizin, müziğin doğamayacağını ifade etmek istemektedir. Böylelikle Rousseau da Aristoteles'in sanat kuramında ifade ettiği gibi sanatı "taklit" ve "hoşlanma" içtepilerine bağlamış olur. Aristoteles, o dönemde tüm sanatları içine alan şiiri ve tüm sanatın temellerini "taklit" (mimesis) ve "hoşlanma" (haz) içtepilerine dayandırmıştır (Aristoteles, 2001, s. 16).

\section{Rousseau'nun Müziğin Doğuşu, Oluşumu ve Modern Müzik Hakkındaki Düşünceleri}

Rousseau'nun müziğin kökenine ilişkin teorilerinin en baskın olduğu perspektif, dilsel ve taklitsel perspektiftir. Bunu, özellikle bu alana yönelik olarak 1781 tarihinde yazdı̆̆ Essai sur l'origine des langues Où Il Est Parlé de la Mélodie et de l'imitation Musicale (Melodi ve Müziksel Taklit ile İlişki İçinde Dillerin Kökeni Üstüne Deneme) adlı eserinden de anlamaktayız.

Filozof, öncelikle düşünce ve duygularımızı ifade etmenin, eş deyişle dışa vurmanın yollarını "görsel" ve "işitsel" olarak ayırır. Görsel iletişimi "hareket"; işitsel iletişimi ise "ses" olarak adlandırmıştır; hareketi dokunma ve jest; sesleri ise dil ve müzik olarak kategorize etmiş̧tir. Gereksinim nedeniyle "ilk jestler"in görsel iletişimi, "güçlü duygulanımlar"dan kaynaklanan ilk seslerin ise işitsel iletişimi oluşturduğunu savunmuştur (Rousseau, 2017, s. 1-9). Bu yönüyle, tıpkı kendisinden hemen sonra gelen aydınlanmacı çağdaşı Herder (1744-1803) gibi dans-melodi-dil üçgeninin, iletişimin işitsel-görsel bütünlüğü anlamında müzik sanatının kökenlerini oluşturduğunu düşünmüştür (Herder ve Bohlman, 2017, s. 249-260).

Rousseau'nun işitsel iletişim teorisi üzerine odaklanacak olursak; o, işitsel iletişimi, eş deyişle dilin ve sözün kökenini, iletişimi gerektirecek güçlü duygulanımlara bağlar (Rousseau, 2017, s. 9-10). Rousseau için müzik, anlamsal bir sistemdir. Rousseau, müzik ve dil üzerine yazılarında insan iletişiminin dinamiklerini doğal bir temele sahip kültürel bir fenomen olarak açıklar (Scott, 1997, s. 812-813). Dillerdeki kültür farklıllğı durumunu ise yerellik, iklim ve dışa kapalı gelenekselliğin zorunluluklarından kaynaklanan bölgesel farklılıklara bağlar (Rousseau, 2017, s. 33-34). Rousseau'ya göre dilsel ve müzikal farkl1lıklar; daha genel olarak kültürel farkl1lıklar, farklı insanların tutkularının spesifik gelişimindeki farklılıklardan kaynaklanmaktadır. İnsanları toplumsallaştıran ve onları yalnız hayvanlardan siyasi bir topluluğun üyelerine dönüştüren her şeyle ilgilenen ve sanatını anlatmaya ve onu memnun etmek için kullanmaya çalışan bir müzisyen olarak Rousseau, sosyal iletişimin tutkulu temelini araştırır (Scott, 1997, s. 805).

Rousseau müziği, mecazi anlatımın ilk ve önemli formlarından biri olması nedeniyle "söz", "mimik", "jest", "hareket", "pantomim" vb. gibi iletişim unsurlarıyla birlikte ele alır (Rousseau, 2017, s. 1-7). Aynı görüş, Rousseau'nun bir sonraki çağdaşı olan Herder'in (1744-1803) müziğin doğuşu ve kökeni üzerine olan 
düşüncelerinde de; “müzik”, “dans”, “mimik”, “jest”, “melodi”, “şiir”, “metin” bütünselliğinin, müziğin ilk ve ayrılmaz parçaları olduğu biçiminde ele alınmıştır (Herder ve Bohlman, 2017, s. 249-260). Herder, müziğin kökenlerine inebilmek için folklorik ve etnografik seyahatler düzenlemiştir (Herder ve Bohlman, 2017, s. 261284).

İlk dilin duygu ve mecaz yüklü olması, dil ve müzikteki prozodi ${ }^{3}$ uygulaması, sözcükleri taşıyan cümlelerin ritmik bölünmelerle şiirsel ve müziksel anlatımlara dönüşmeye başlaması (ilk halk edebiyatı ve müziği örnekleri), bu ses oluşumunun evrilerek ritim, melodi ve armoni yapılarını oluşturması gibi saptamaları, Rousseau'nun, dillerin ve müziğin kökenini bir bütün olarak ve aynı kaynaktan çıktı̆̆ biçiminde algıladığını gösterir. Rousseau'nun müziğin kökenlerini ele aldığı çalışmasının Melodi ve Müziksel Taklit ile İlişsi Iç̧inde Dillerin Kökeni Üstüne Deneme adını taşıması bile, filozofun müziğin kökenini "taklit”, "hoşlanma”, "dil” ve "müziksel öğeler” (melodi, ritim, armoni vb.) ile bir bütün olarak düşündüğünü göstermektedir.

Rousseau, dil ve müziği ortak bir kökene bağlaması nedeniyle dilsel vurgu ve müziksel prozodiyi de akraba olarak kabul etmekte ve aynı köke dayandırmaktadır. Bunu Halikarnassoslu Dionysos'tan aldığı alıntı ile şu biçimde ifade eder: "Halikarnassos'lu Dionysos, tonun tiz vurguda yükselmesinin ve pes vurguda alçalmasının bir beşinci aralık kadar olduğunu söyler; aynı biçimde prozodi vurgusu, özellikle de sesin bir beşinci aralık ölçüsünde yükselip aynı hecede başka bir beşinci aralık ölçüsünde düştüğü vurgusu da müzikseldi...” (Rousseau, 2017, s. 29).

Rousseau'nun dil, söz ve müziği ortak bir kökene bağladığı en önemli ifadelerinden biri de, Strabon'dan aktardığı "söylemek ve şarkı söylemek eskiden aynı şeylerdi” ibaresidir (Rousseau, 2017, s. 58). Etnomüzikolog B. Nettl, halen İran'da şarkı söylemek için kullanılan khandan sözcüğünün İngilizceye "okumak" (reading), "söylemek" (singing) ve "reçite etmek" (reçitate) biçiminde karşıllk geldiğini söylemektedir (Nettl, 1983, s. 20). Bu kullanımın, kadim Anadolu müzik geleneğinde (türkü/deyiş okumak/söylemek) (Mustan Dönmez, 2009, s. 109-113) ve farklı geleneklerde de bu şekilde (okumak/söylemek) kullanılmasındaki en önemli neden bu olsa gerek. Bu düşünceden (dil-müzik özdeşliği) yola çıkan Rousseau, ilk yasaların şarkı formunda olduğunu ve belagat, müzik, şiir ve dilin başlangıçta ortak bir kökene sahip olduğunu, böylelikle dilin hem tutarlı düşünceleri hem de duygulanımları anlatabildiğini ve Antik Yunan'da zamanında var olup bugünün toplumlarında olmayan yegâne etkenin bu olduğunu söyler. Ayrıca filozof, her toplumun kendi müziğinden haz alıp en çok kendi müziğini anlamlandırabiliyor olmasını da, müziğin dille ortak bir tavır göstermesine bağlamaktadır:

Keyfimize uygun en güzel şarkılar, ona hiç alışkın olmayan bir kulağı hep şöyle böyle etkileyecektir; bu, sözlüğüne sahip olmamız gereken bir dildir (Rousseau, 2017, s. 65)... Bir İtalyan’a İtalyan ezgileri, bir Türk’e Türk ezgileri gerekir. Herkes sadece kendisine tanıdık gelen vurgulardan etkilenir... Söylenenin kişiyi harekete geçirebilmesi için konuşulan dili anlaması gerekir (Rousseau, 2017, s. 70).

Rousseau'nun, felsefesiyle "uygarlığın açmazlarından" ve yol açtı̆̆g "toplumsal yozlaşma"dan haberdar ettiğini, bilhassa "Emile”, "Toplumsal Sözleşme”, "Bilimler ve Sanatlar Üzerine Söylev”, "İnsanlar Arasındaki

\footnotetext{
${ }^{3}$ Prozodi: "Sözlü bir müzik yapıtında, sözcüklerin vurgulu ve vurgusuz heceleriyle, ölçünün kuvvetli ve zayıf zamanları arasındaki uygunluk. Operada librettoyla müzik; klasik Türk müziğindeyse aruz ölçüsüyle makam arasındaki uyum gibi" (Sözer, 2012, s. 194).
} 
Eşitsizliğin Kaynă̆l” gibi eserlerinden de bilmekteyiz. Rousseau'nun tasavvuruna göre, grup halinde şark1 söylemek ve dans etmek için yapılan ilk toplanmalar çok geçmeden kimin en iyi şarkı söyleyip dans ettiği kavgaları üzerinden kıskançlık ve eşitsizliğe yol açıyor ve işte insanlık bu andan itibaren baş aşağı yuvarlanmaya başlamış oluyordu (Shiner, 2017, s. 230-231). Rousseau, “Insanlar Arasındaki Eşitsizliğin Kaynă̆̆” adlı eserinde, sanatsal ve müziksel anlamdaki eşitsizlik ve yozlaşmanın kaynağını ise, şu şekilde ifade etmektedir: "Kim en iyi şarkı söyleyip dans ettiyse, kim en güzel, en güçlü, en hünerli veya en belagatlı ise, en sayılan kişi oldu. Bu, eşitsizliğe ve aynı zamanda yozlaşmaya doğru atılan ilk adımdı. Bu ilk ayrımlardan, bir yanda kibir ve küçümseme diğer yanda utanma ve kıskançlık doğdu" (Rousseau, 2003, s. 71).

Rousseau'nun çağındaki müziğe yaklaşımı da genel felsefesinden kopuk değildir. Tıpkı uygarlık, bilim ve sanat gibi dönemi müziğinin de aslından uzaklaştığını iddia etmiştir. Bu konu üzerindeki düşüncelerine bakıldığında, bunu dil yetkinliğiyle açıklamıştır. Rousseau, dil yetkinliğinin melodiyi kurallara bağladığından ve sınırlandırdığından, melodinin kurallara bürünmesinin yavaş yavaş eski enerjisini kaybetmesine yol açtığından bahsetmektedir. Ses tonundaki değişimlerde var olan yüksekliklerin yerini ise aralık hesabının aldığını ifade etmiştir. Rousseau'ya göre ikna sanatı geliştirildikçe duygulandırma sanatı kaybedilmiştir. Yunanistan'dan “zincire vurulan” diye bahseden Rousseau, Yunanistan’ın “özgür ruhları 1sıtan ateşi”ni kaybettiğini, Romalılarla karışma ile dildeki armoninin ve vurgunun zayıfladığını, daha sert ve daha az müziksel bir dil olan Latin dili ile oluşturulan müziğin var olana zarar verdiğini belirtmiştir (Rousseau, 2017, s. 81-82).

Dolayısıyla müzikte eş yedirimli tampere sistem ${ }^{4}$, doğada olmayan mekanik bir aralık düzeni sağladığı ve gücünü tampere sistemden alan armonik oluşum melodik ifade ve hareketliliği kısıtladığı için; enstrumantal (çalgısal) müzik ise, müziğin sözsel/metinsel derinlik ve ifadesini yok ettiğinden Rousseau tarafindan eleştirilmiştir. Ayrıca Rousseau, müziğin hakikat ve anlam yüklü yapısını oluşturan sözlerin önemsenmemesi; dil yetkinliğinin artmasıyla dilin melodiden ayrılması ve melodinin özerklik kazanması; dolayısıyla müzik öğelerinin birbirinden bu biçimde koparılmasının, Yunan tragedyalarına ait bütüncül anlayışın ortadan kalkmasını sağlayarak müziği yozlaştırdığını şu şekilde savunmuştur: “...Böylece müzik, sadece şiirin vurgusu ve armonisiyken ve sözün daha sonra sadece akıl üzerinde kuracağı etkiyi güçlü duygulanımlar üzerinde kurmuşken yarattığı mucizeler de görülmez oldu. Aynı şekilde, Yunanistan sofistler ve filozoflarla doldukça orada artık ne ünlü şairler ne de ünlü müzisyenler yaşar oldu” (Rousseau, 2017, s. 82).

\section{Sonuç}

J. J. Rousseau, felsefe ve sosyolojinin önemli temsilcilerinden olan etkili bir 18. yy. Aydınlanma Dönemi filozofudur. Ayrıca bestecilik, müzik teorisyenliği, dilbilim, ekonomi, siyaset, hukuk, pedagoji gibi birçok alanda eser vermiş çok yönlü bir entelektüeldir. Rousseau, kendi döneminde, bugünkü çağın düşünce, ahlak ve eğitim sistemi ile ilgili birçok öngörüde bulunmuş ve "yanlışlıkları değiştirme” ihtimali içerisinde insanlığa sesini duyurmayı hedeflemiştir.

Rousseau, “toplum sözleşmesi”, “genel irade”, “uygar insan”, “doğa durumu”, “demokrasi”, “özgürlük” ve “eşitlik” gibi kavramları yeniden ve farklı bir açıdan ele almasıyla dikkat çekmiştir. Özellikle "toplumsal sorunlar" ve "eşitsizlik" meselesini çok önemsemiştir. İnsanlığın uygarlık yönündeki yürüyüşünün insanlığı eşitsizliğe götürdüğünü iddia ederek bilimde, sanatta ve toplumsal yapıda doğacılığı savunmuştur. Rousseau, özel mülkiyet

\footnotetext{
${ }^{4}$ Tampere Sistem: “Bir oktavın 12 eşit aralığa (yarım tona) bölündüğü akort düzeni” (Sözer 2012, s. 232).
} 
sistemi üzerine inşa edilen medeniyetin, toplumsal sınıfları, eşitsizliği, lüks tutkusunu ve yozlaşmayı sağladığını iddia ederek, aynı zamanda 1848'de yayımlanan “komünist manifesto"nun da erken habercisi olmuştur.

İşte Rousseau'nun müzik üzerine olan düşünceleri de bilim ve sanat üzerine olan düşüncelerinden bağımsız değildir. Rousseau'nun besteciliği, müzik teorisyenliği ve müzikologluğu, kaynağını kendi özgün felsefi sisteminden almıştır. Rousseau'nun Antikiteye duyduğu özlem ve günümüz modern toplumuna ve sanatına olan tepkili yaklaşımı, onun müzik anlayışına da yansımıştır: Rousseau, dönemi sanatının ve müziğinin aşırı şaşalı, öğrenmesi zor ve duyguların direkt anlatımına izin vermeyen sistemini eleştirmiştir. Rousseau'nun doğacıllığı ve Batı müziğine yaptığı bu acımasız eleştiri, gelecek yıllarda, özellikle filozof J. G. Herder'in öncülüğünde oluşan "folklorizm” ve “müzik etnolojisi” düşüncesine de kapı aralamıştır.

Rousseau'nun müziğin kökeni ve doğuşu ile ilgili düşüncelerine gelince, müziğin kökenini tıpkı Aristoteles (2001) gibi taklit (mimesis) kuramına bağlamış; ayrıca Herder (2017) gibi müziğin, dilin ve jestlerin-mimiklerin kökenini, seslere dayalı iletişimin kaynağı olması nedeniyle bir bütün olarak algılamış ve müziğin kökenini dil, melodi ve ritimde aramıştır (Rousseau, 2017).

Rousseau, sözü besleyen temel unsurun melodi olduğunu düşünmesinden dolayı müzikte en az melodi kadar söze de önem vermiştir. O, bu durumun nedenini şöyle ifade etmiştir: "Müzik, sözel vurguyu bırakıp sadece armonik yapılara bağlanarak kulağa daha gürültülü ve kalbe daha az yumuşak gelir hale bürünüyor. Müzik artık konuşmuyor zaten, yakında şarkı da söylemez olacak ve bütün o akorları ve armonisiyle üzerimizde hiçbir etki bırakmaz hale gelecek (Rousseau, 2017, s. 77).

Rousseau, müziğin yapay bölümlendirmelerle on iki tona, makamın ise majör-minör olarak ikiye indirgenmesi sonucu doğan armoni sanatının, müziği aşırı karmaşıklaştırması ve nota yazımının pratik olmayışı yönüyle Batı Sanat Müziğini kökten eleştirmektedir. Rousseau'nun armoniye yüklediği olumsuz anlamlardan biri de armoninin melodik gidişin özgürlük ve enerjisini ortadan kaldırmış olması biçimindedir (Rousseau, 2017, s. 65-68). Eş deyişle dikey müzik besteciliği (armoni sanatı), doğası gereği anlatımın yatay yönü olan melodik yönünü kısıtlamaktadır. Böylelikle Rousseau'ya göre müzik de insanlığın diğer kültür alanları gibi “yozlaşmış" ve "aslını kaybetmiş̧ir." Dil gelişmeye başladıkça ikna sanatı da gelişmiştir. Dil kaynaklı ikna sanatının gelişimi ise, dilin müzikten el çekmesi suretiyle müzikte duygusal anlatımın yavaş yavaş kaybolmasına sebep olmuştur. Aynı şekilde melodi de kurallara bağlanmış ve eski etkisini böylece kaybetmiştir.

Rousseau'nun temel alanının felsefe olduğu ve müzik alanında yeterli eğitim alamadığı göz önünde bulundurulup çağdaşları nezdinde değerlendirildiğinde, müzik teorisi ve bestecilik alanında ileri düzey bir performans sergilemediği düşünülmüştür. Ancak burada müzikoloji açısından önemli olan, Rousseau'nun teorisyenliği ya da besteciliğinden çok müzik üzerine ortaya attığı düşüncelerinin felsefi sistemiyle olan bağlantısı ve geleceğe yön vermesidir. Doğayla uyumlu ve arı felsefesinin bilim ve sanat anlayışına da yansıması; müziği hakikati kavratan bir gereç olarak algılaması ve bu yönüyle Antikiteye özenmesi; dolayısıyla müziğin gösterişli yönünden çok özünü kavratmaya ve sonraki kuşaklara aktarmaya yönelik düşünsel yaklaşımına uygun, basit nota yazım yöntemleri tasarlaması; melodide matematiksel aralık hesabını olumsuzlaması; söz ve melodiye tampere sistem gibi olmayıp doğaya daha uygun olması yönüyle armoniden daha fazla değer vermesi, bu filozofun düşünceleri, söylemleri ve uygulamaları arasındaki doğrusallı̆̆ı göstermesi açısından önemlidir. 


\section{Kaynakça / References}

Akan, N. (2017). Jean-Jacques Rousseau ve Müzik. İstanbul Aydın Üniversitesi Güzel Sanatlar Fakültesi Dergisi. $3(5), 23-30$.

Alsan, N. (1962). Jean- Jacques Rousseau Hayatı, Sanatı, Eseri. İstanbul: Varlık Yayınevi.

Aristoteles (2001). Poetika. Çev. İsmail Tunalı, İstanbul: Remzi Kitabevi.

Bakır, K. (2007). Jean-Jacques Rousseau'nun Natüralist Eğitim Anlayışı. Kâzım Karabekir Eğitim Fakültesi Dergisi. 15, 103-122.

Cevizci, A. (2007). Felsefeye Giriş. Bursa: Sentez Yayınları.

Cevizci, A. (2008). Aydınlanma Felsefesi Tarihi. Bursa: Asa Kitapevi.

Cevizci, A. (2017). Aydınlanma Felsefesi. Say Yayınları: İstanbul.

Engineri, M. (2008). Uygarlık Tarihi, Aydınlanma Çağı ve Felsefesi Adlı Konunun Araştırılması. Mersin Üniversitesi, Güzel Sanatlar Fakültesi Dergisi, 1-15.

Ertuğrul, T. (2020). Rousseau'nun Müzik Teorisinin Yapısökümü. Felsefi Düşün Akademik Felsefe Dergisi, 15, 40-69.

Herder, J. G. and Bohlman P. V. (2017). Song Loves The Masses: Herder on Music and Nationalism. California: Universty of California Press.

İşler, E. (1999). Voltaire ve Rousseau Etrafında Aydınlanma Çağı Fransız Yazını'na Bir Bakış. PAÜ, Ĕ̌itim Fakültesi Dergisi, 5, 48-53.

Lovejoy, A. O. (1923). The Supposed Primitivism of Rousseau's "Discourse on Inequality. Modern Philology, The University of Chicago Press, 21(2), 165-186.

Mustan Dönmez, B. (2009). Anadolu Tasavvufunda Ritüel Müziğinin Kültüre Gömülü Olma ve Anıștırılma Durumlar1, Folklor Edebiyat, 58, 107-115.

Mustan Dönmez, B. (2015). Müziğin Kökeni Üzerine. Ankara: Gece Kitaplığı.

Mustan Dönmez, B. (2019). Etnomüzikolojinin Temel Kavramları. İstanbul: Bağlam Yayınları.

Nettl, B. (1983). The Study of Ethnomusicology: Twenty-nine Issues and Concepts. Chicago: University of Illinois Press.

Oransay, G. (1977). Bă̆garlar Geçidi. İzmir: Küğ Yayınları.

Rousseau, J. J. (1975). Complete Dictionary of Music. Çev. French W. Waring, New York: AMS Press.

Rousseau, J. J. (1991). Ittiraflar II. Çev. Arif Obay, İstanbul: Milli Eğitim Basımevi.

Rousseau, J. J. (1998). Essay On The Origin of Languages and Writings Related to Music. Trans. and ed. by Scott, T. J., New England, Hanover and London: Published by Dartmouth College University Press.

Rousseau, J. J. (2003). Insanlar Arasındaki Eşitsizliğin Kökeni. Çev. Ertuğ Ergün, Ankara: Yeryüzü Yayınevi. 
Rousseau, J. J. (2017). Melodi ve Müziksel Taklit ile ilişki Iç̧inde Dillerin Kökeni Üstüne Deneme. Çev. Ömer Albayrak, İstanbul: Kültür Yayınları.

Rousseau, J. J. (2018). Bilimler ve Sanatlar Üstüne Söylev. Çev. Sabahattin Eyüboğlu, İstanbul: Kültür Yayınları.

Scott, T. J. (1997). Rousseau and the Melodious Language of Freedom. Chicago: The University of Chicago Press, 803-829.

Shiner, L. (2017). Sanatın İcadı Bir Kültür Tarihi. Çev. İsmail Türkmen, İstanbul: Ayrıntı Yayınları.

Sözer, V. (2012). Müzik Terimleri Sözlüğ̈̈. İstanbul: Remzi Kitabevi.

Topses, M. D. (2010). Aydınlanma Sosyolojisi. Ankara: Anı Yayıncılık.

Tylor, E. (1949). Rousseau's Conception of Music. Music and Letters, Oxford Universty Press, 30/3, $231-242$.

Weber, A. (1991). Felsefe Tarihi. Çev. Vehbi Eralp, İstanbul: Sosyal Yayınlar.

\section{EKLER:}

\section{EK 1: J. J. ROUSSEAU'NUN BAŞLICA YAPITLARI}

a. Siyaset, Hukuk ve Toplum Felsefesi Üzerine:

1. Bilimler ve Sanatlar Üzerine Söylev (1750- İlk Söylevi)

2. Insanlar Arasındaki Eşitsizliğin Kaynă̆ı ve Temeli Üzerine Söylev (1755- İkinci Söylevi)

3. Ekonomi Politik Üzerine Söylev (1755)

4. Toplum Sözleşmesi (Politik Hukuk İlkeleri- 1762)

5. Korsika Anayasası (1765)

\section{b. Eğitim Üzerine:}

1. Emile (1762)

c. Kendi Üzerine:

1. Itiraflar (1782-86)

2. Rousseau, Jean-Jacques'i Yargllyyor (1772- 76)

3. Yalnız Gezerin Düşleri (1782)

\section{d. Müzik, Dil ve Tiyatro Üzerine:}

1. Modern Müzik Üzerine Deneme (1742)

2. Çağdaş Müzik Üzerine Bilimsel İnceleme (1743)

3. Çapkın Periler Operası (1745)

4. Köyün Kâhini Operası (1752)

5. Fransız Müziği Üstüne Mektup (1753)

6. Nergis (Komedi) (1753)

7. Tiyatro Oyunlarl Üstüne d'Alembert'e Mektuplar (1758)

8. Müzik Sözlüğ̈̈ (1764-68)

9. Dillerin Kökeni Üzerine Bir Deneme (1755-60)

EK 2. J. J. ROUSSEAU'NUN MÜZIKKSEL YAŞAM KRONOLOJİİ (Rousseau: Scott önsözü, 1998: 1xxi1)

1712

-28 Haziran: Jean-Jacques Rousseau, Cenevre'de doğar.

1728

-14 Mart: Rousseau, Cenevre'den kaçar; 1729 yazına kadar İtalya'ya seyahat eder.

1729

-Yaz-Güz: Rousseau, Lazarist Semineri'nde çalışır ve ardından M. Le Maître ile müzik çalışmaya başlar. 1730

-Kış: Rousseau, Neuchâtel'de müzik öğretir. 
1731

Rousseau, müziği ticari amaçla kopyalamaya başlar.

1732

-Haziran: Rousseau, Chambéry'de müzik öğretmeye başlar.

1733

-Temmuz: Rousseau, Abbé Blanchard ile müzik eğitimi almak için Besançon'a gider. (Tarih belirsiz.)

1734

-Sonbahar: Rousseau, Rameau'nun Treatise on Harmony (Armoni Üzerine İncelemesi) eserini satın alır ve üzerinde çalışır. Mme de Warens'in Chambéry'deki müzik akşamlarını yönetir.

1737

-Haziran: Rousseau'nun ilk yayını, A Song (Bir Şarkı), Mercure de France'da yayınlandı.

1741

-Aralık Sonu: Rousseau, müzik notasyonu için yeni sistemiyle Paris'e gelir.

1742

-22 Ağustos: Rousseau, Bilimler Akademisine Müzik İçin Yeni İşaretler planını okur.

1743

-Ocak: Rousseau'nun Dissertation on Modern Music (Modern Müzik Üzerine Tez) eserinin Yayını.

-10 Temmuz: Rousseau, Fransa'nın Venedik Büyükelçisinin sekreteri olarak Paris'i terk eder. İtalyan müziği ile yeniden tanışır.

1744

-6 Ağustos: Rousseau, Venedik'ten ayrilır ve Paris'e döner.

1745

-Temmuz: Rousseau, Les Muses Galantes'i (Cesur Müzler) tamamladı.

-Eylül: Rousseau'nun Les Muse Galantes’i (Cesur Müzler), Rameau'nun Rousseau'yu intihalle suçladığı La Poplinière'nin evinde sergileniyor.

-Sonbahar: Rousseau, Voltaire'in librettosu ve Rameau'nun müziği ile Les Fêtes de Ramire'yi (Ramire'nin Ziyafetleri) çalışıyor. Çalıșma, Aralık ayında Versailles'da Rousseau'ya haber verilmeksizin sunuldu.

1749

-Ocak-Mart: Rousseau, Encyclopedia için müzik üzerine makaleler yazıyor.

-Ekim: Illumination of Vincennes (Vincennes Aydınlatması): Rousseau, Dijon Akademisi tarafindan önerilen deneme konusunu okur.

1750

-Temmuz: The First Discourse (İlk Söylem), Dijon Akademisi tarafindan ödüle layık görüldü.

1751

-Ocak: The First Discourse'un (İlk Söylem) yayınlanması.

-Şubat: Rousseau, Dupin ailesindeki işinden ayrılır ve bir müzik kopyacı olarak çalıșır.

-Temmuz: Rousseau'nun müzik üzerine makalelerini içeren Encyclopedia'nın birinci cildinin yayınlanması.

1752

-Kış-İlkbahar: Rousseau, Fransız Müziği Üzerine Mektup’u yazar.

-Mart: Grimm'in Omphale Üzerine Mektup'unun ve Raynal'ın Grimm'in “Omphale” Mektubu Üzerine Açıklamaları'nın Yayınlanması.

-Nisan: Rousseau'nun Omphale Hakkındaki Mektuba Eklenen Açıklamalar Konusundaki Grimm'e Mektubunun Anonim Yayını.

-İlkbahar: Rousseau, Le Devin du Village (Köy Kâhini) eserini oluşturur.

-Haziran: Rousseau'nun Fontainebleau'daki Le Devin du Village (Köy Kâhini) performansı. Rousseau, XV. Louis tarafindan sunulan emekli maaşını geri çevirir.

-1 Ağustos: Pergolesi'nin gezgin bir İtalyan grubu tarafindan sergilenen La Serva Padrona adlı başarılı performansiyla Bouffons Kavgasinın Paris'te patlaması.

1753

-1 Mart: Rousseau'nun Le Devin du Village (Köy Kâhini) Operası'nın Paris Operası'ndaki performansı.

-Eylül: Rousseau'nun Bir Senfonistten Mektup'un anonim yayını.

-Kasım: Rousseau'nun Fransız Müziği Üzerine Mektupunun yayınlanması. Rousseau, İkinci Söylemi yazmaya başlar.

1754

-12 Haziran: Rousseau, ithafinı İkinci Söylem'e dayandırır. Rameau'nun Observations on Our Instinct for Music (Müzik İçgüdümüzle İlgili Gözlemler) eserinin anonim olarak yayınlanması.

1755

-24 Nisan: Rousseau'nun Ikinci Söyleminin Yayını.

-Ağustos: Rameau'nun Errors on Music in the Encyclopedia (Ansiklopedide Müzik ile İlgili Hatalar) yayınlanmas1.

-Sonbahar: Rousseau, Rameau'nun Müzik Üzerine Hataları'na yanıtının ilk taslağını yazıyor. 
1756

-Mart: Rameau'nun Continuation of the Errors on Music in the Encyclopedia (Ansiklopedide Müzik ile ilgili Hataların Devam Etmesi) yazısının anonim yayını.

-Mayıs: Ansiklopedinin 6. cildi, Diderot ve d'Alembert'in Rousseau'yu Rameau'ya karşı savunduğu "Bildiri"yi içeriyor.

1758

-İlkbahar: Rousseau'nun On Theatrical Imitation (Teatral Taklit Üzerine) adlı eseri, d'Alembert'e Mektup olarak hazırlanmıştır.

1761

-Eylül: Rousseau, Essay on the Origin of the Languages (Dillerin Kökeni Üzerine Deneme) adlı eseri yayınlamayı tavsiye eden Malesherbes'e gönderir.

1762

-9 Haziran: Rousseau'nun Emile'nin yayınlanmasından sonra tutuklanması için bir izin çıkarıldı; Fransa'dan Cenevre'ye kaçtı. Levite of Ephraïm (Levilli Efhraïm) Bestesi.

1763

-İlkbahar: Rousseau, On Theatrical Imitation (Teatral Taklit Üzerine), Essay on the Origin of Languages (Dillerin Kökeni Üzerine Deneme) ve The Levite of Ephrä̈m'i (Levilli Efrahim) birlikte yayınlamayı düşünür, ancak bunun tersi karar verir.

1764

-Kış: Rousseau'nun On Theatrical Imitation (Teatral Taklit Üzerine) eserinin yayını.

1765

-Rousseau, Examination of Two Errors (İki Hatanın İncelenmesi) metnini, Müzik Sözlüğ̈̈'nün bir önsözü olarak kullanmak niyetiyle sonlandırır. (tarih belirsiz)

1768

-Rousseau'nun Müzik Sözlüğünün Yayını.

1770

-Mayıs: Rousseau'nun Pygmalion'unun ilk performansı.

-Aralık: Rousseau, Charles Burney ile tanışır.

-Şubat: Rousseau, açıkça himayesi altına giren Gluck ile tanışır.

-Ağustos: Gluck'un Paris'te Orphée (Orpheus) operasının ilk gösterimi. Extract from a Response by the Underlaborer to his Frontman (İş̧inin Lidere Verdiği Yanıttan Alıntı) yazısının taslağı için en erken tarih.

1774

-Şubat: Rousseau, Gluck'la buluşur, Rousseau'nun açıkça hamiliğinde yer alır.

-Ağustos: Gluck'un Orfee'si (Orpheus) ilk kez Paris’te sahnelenir.

1775

-Mart: Rousseau'nun Fragments of Observations on Glucks Italian “Alceste” (Gluck'un İtalyan Alcestesi Üzerine Gözlemler) eserinin muhtemel tarihi, daha sonra Burney'e Mektup'a eklendi.

-20 Ekim: Rousseau'nun Pygmalion operasının Paris Operasında performansı.

1776

-Aralık: Rousseau'nun Devin du Village (Köy Kâhini) Operası, Paris Operası'nda yeniden canlandırıldı ve Gluck'un Orphée'siyle (Orpheus) birlikte çalındı.

1777

-Ekim: Rousseau'nun Burney'e Mektup yazısının muhtemel tarihi.

1778

-2 Temmuz: Rousseau, Ermenonville'de öldü. 